\title{
D. Bedrii
}

Candidate of Technical Sciences, Deputy Director for Science dimi7928@gmail.com, orcid.org/0000-0002-5462-1588

Ukrainian Scientific Research Institute of Radio and Television, Ukraine

\section{INTEGRATED ANTI-RISK MANAGEMENT OF CONFLICTS OF A SCIENTIFIC PROJECT IN A BEHAVIORAL ECONOMICS}

\begin{abstract}
The object of the research is the processes of managing uncertainties such as risks, conflicts, and factors of behavioral economics which may have negative consequences for a scientific project. The study has revealed that the success of any project depends on the ability of the project manager to effectively manage his team to meet the values of each stakeholder and the goals of the project itself. To solve this goal it is necessary to complete the following tasks:

- analysis of methods of integration of risk management, conflicts and factors of behavioral economics;

- justification of the necessity to build integrated anti-risk management of conflicts in behavioral economics;

- to carry out conceptual modeling of integrated anti-risk conflict management in behavioral economics.

A conceptual model of integrated anti-risk management of conflicts of a scientific project in the context of behavioral economics is proposed, built based on the "Change Management Iceberg" model. The management of scientific projects has been further developed through the integration of methodologies: project management, the theory of stakeholders, risk management, HR management, conflict management, and behavioral economics. A conceptual scheme of integrated anti-risk management of conflicts of a scientific project in behavioral economics has been developed which allows a project manager to manage uncertainties (risks, conflicts, factors of behavioral economics).

Research refers to the project management methodology and improves it by integrating the processes of risk, conflict, and behavioral economics management into one process. The main goal of the study is to reduce and eliminate all negative consequences in a scientific project, to complete it within the approved budget, terms and a certain quality.

Keywords: project management methodology, scientific project, "iceberg” model, integrated anti-risk management, conflict, factors of behavioral economics.

\section{Introduction}

Today, new approaches to the management of any sphere of human activity are being successfully implemented all over the world. The project management methodology deserves special attention, in particular, the application of its practices, principles, processes, tools and methods. The methodology allows managing projects in terms of more limited budgets, short deadlines, a lack of resources and rapidly changing technologies [1].
\end{abstract}


The business environment is characterized by high dynamics with the pace of change, which is constantly accelerating. To maintain the competitiveness in the conditions of a global economy, companies are actively moving to project management to achieve consistent business value [2].

Effective and efficient project management should be considered as a strategic competence in the organization. It allows to:

- link project results with business goals;

- compete more successfully in their markets;

- to achieve the stability of their organization;

- respond to changes in the business environment for projects by properly adjusting project management plans.

Each project has stakeholders who are affected by the project or can affect the project in a positive or negative way. The ability of a project manager to correctly identify and properly manage all stakeholders can determine the success or failure of a project. To increase the chances of success before the process of identification and involvement of stakeholders, it is necessary to start as soon as possible after the approval of the statute [1, 3].

Stakeholder satisfaction should be defined and managed as one of the project's objectives. The effectiveness of attracting stakeholders is:

- paying attention to constant communication with them including team members to understand their needs and expectations;

- solving problems as they arise;

- risk prevention and conflict resolution;

- stimulating the involvement of stakeholders in the decision-making and project work;

- taking into account the factors of behavioral economics [1, 4, 5, 6].

Based on the above, it is clear that project activities, in most cases, can be carried out in conditions of uncertainty, including risks, conflicts, and behavioral economics. This also applies to research projects which differ from other types of project activities in that they are implemented in conditions of uncertainty of the research itself [7].

Therefore, in the current conditions of the variability of the project environment and its uncertainty, a new methodology of integrated risk management of scientific project conflicts in behavioral economics is needed.

\section{Research of existing solutions of the problem}

The success of any project depends on the ability of the project manager to effectively manage his team in order to achieve the values of each stakeholder and the goals of the project itself. Today, scientists all over the world in their research pay much attention to the convergence, hybridization, and integration of different methodologies to ensure the success of project management $[8,9,10]$.

Bushuyev S.D. in [8] grounded the need to develop hybrid methodologies for project management, programs, and project portfolios. This is better because significant reductions in the life cycles of infrastructure programs, which include projects of various activities and different management methodologies, including "waterfalls" with a rigid life cycle and Agile with a flexible life cycle methodology, require the use of convergence tools to form "Hybrid" methodologies. The application of convergence and hybridization technologies for the creation and adaptation of project management methodology is determined by the characteristics of the project, its complexity, scale, requirements for success criteria, the organizational structure in which it is implemented. However, the effective use of these technologies depends on the level of competence of the project manager, collective competence, and in general the level of maturity of project management in the enterprise. 
In [9], the authors analyzed the development trends of infrastructure management systems, which showed that the key factors are the reliability of implementation, efficiency in creating values, and environmental harmonization. At the same time, increasing the level of efficiency of infrastructure programs are strategic directions for development in most countries of the world. It is important in turbulent conditions to build a hybrid multilevel methodology for managing infrastructure programs based on a convergent balanced approach. The methodology of multilevel proactive dual management of infrastructure projects on the basis of adaptive technologies is based on three interconnected adaptive systems: planning and formation, monitoring and change management, and regulates the formation of disturbance in the management process.

The author in [10] considered the problem of forming a qualitative process of goal setting in the program of large projects that are performed in conditions of high uncertainty. Particular attention is paid to converged technologies to minimize targeting uncertainties associated with internal sources. It is revealed that convergent management technologies are a set of methods and means of combining different management methodologies in order to identify generalized elements of self-organization in this process.

Piterskoyu V.M. in [11] a new methodology of risk-oriented management of scientific activity of higher education institutions is proposed, which allows increasing the efficiency of innovative programs with the help of models and methods of project-oriented management of interaction processes within the triune spiral "University-State-Business". This study is more about innovation but can be the basis for its application in the management of research projects.

In [12] the methodology of integrated deviation management in projects was developed, which allowed the project manager to manage integrated, systematically, all causes of deviations (risks, changes, problems, conflicts, stresses, crises) in the project. The results of this study provide tools for the development of integrated risk management but do not take into account the factors of behavioral economics, the study of which is very relevant today.

The authors in $[6,13,14]$ paid attention to the study of behavioral economics that arise in the process of stakeholders and have a significant impact on the success of any human activity, including the project.

In order to successfully implement the project and meet the needs of its stakeholders, the project manager and his team need to form an effective policy of human resources management and project stakeholders at the project initiation stage. In particular, at this stage, it is necessary to solve a number of specific tasks related to work motivation, conflicts, performance, control, responsibility, communications, power, leadership, etc. [3].

This, in its turn, allows you to create favorable conditions for work, helps to overcome the huge mental strain that arises in the process of finding, agreeing and implementing project solutions, avoids conflicts and stress, take into account the factors of behavioral economics that may ultimately affect the relevant levels, quality and timeliness of project implementation [15].

Scientific projects are no exception because one of their features is the complexity of its implementation, in particular, their main performers are scientists [16]. In the activities of scientific institutions, each scientific project has a unique result, limited execution time, a certain cost, and certain requirements for future results.

Based on the fact that the scientific result is new scientific knowledge, which is obtained in the process of basic or applied research and recorded in the form of a report, research report, scientific discovery, etc., the features of the scientific project are unconventional and time-consuming. 
Unconventionality is explained by the fact that during the implementation of a scientific project, scientists have to conduct, in most cases, the study of the subject area in terms of the uncertainty of its further development.

Implementation of scientific projects is a labor-intensive activity in which the majority of the time, material, labor, and financial resources are spent on scientific research in order to obtain scientific and scientific-technical results [16].

In addition to the project manager, his team, and the direct executors (scientists) of the scientific project, there are also stakeholders who are affected by the project or can affect it in a positive or negative way. In particular, the influences in the scientific project can include risks, conflicts, and factors of behavioral economics [15]. Therefore, the ability of a project manager to correctly identify and properly manage all stakeholders can determine the success or failure of a project.

Thus, based on the above, it is clear that today there is a necessity to develop a methodology for integrated risk management of conflicts in behavioral economics in scientific projects that are planned and implemented in conditions of uncertainty.

\section{The purpose and objectives of the study}

This study aims to develop a conceptual model of the integrated conflict management scientific project in behavioral economics.

To achieve this goal it is necessary to perform the following tasks:

- analysis of methods of integration of risk management, conflicts, and factors of behavioral economics;

- justification of the necessity to build integrated anti-risk management of conflicts in a behavioral economics;

- to carry out conceptual modeling of integrated anti-risk conflict management in a behavioral economics.

\section{Methods of research}

Management of any project can be considered as a set of processes and operations carried out in order to achieve project objectives. Some of these processes can be carried out only once, but others are carried out in parallel and several times during the project $[1,2,4]$. One example of a parallel and multiple iteration of a process is a change of the requirements that affects the content, schedule, or budget and needs request for changes. Some project management processes, such as the content control process and the integrated change control process, may require request for changes. The process of integrated change control is carried out throughout the project life cycle in connection with the integration of request for changes $[1,17]$.

Although there is no permanent definition of the integration of project processes, it is obvious that the project will have little chance of achieving its goals if the project manager is unable to integrate project processes in cases of their interaction.

The role of the project manager in the implementation of project integration is twofold:

- plays a key role in the interaction with the sponsor to understand the strategic goals and ensure that the objectives and results of the project are aligned with the objectives and portfolio, program and business areas;

- is responsible for ensuring the joint work of project team members with an emphasis on what is important at the project level.

Some projects may be complex and difficult to manage. Complexity in projects is the result of the behavior of the organizational system, the behavior of people and the uncertainty that 
exists in the organization or the environment. In [18], these three dimensions are defined as follows:

- system behavior - factors of interdependence of components and systems;

- human behavior - interaction between different people and groups;

- uncertainty - uncertainty of problems that arise and lack of understanding or confusion.

Complexity in itself is a person's perception based on his personal experience, observations, and skills. It is possible to define the project more precisely as not difficult, and as containing complexity.

In considering the complexity of the project, the project manager must take into account the elements that are both inside and outside the project.

The complexity of a project, as its characteristics and properties, is usually defined as a project that:

- contains many parts;

- has a number of connections between the parts;

- demonstrates dynamic interactions between parts;

- exhibits the types of behavior that arise as a result of these interactions, which cannot be explained by the simple addition of parts, namely emergent behavior.

Thus, this study uses methods and tools from such areas of knowledge of classical project management methodology as integration, resource and project's stakeholders [1, 2], as well as proposed in [19] the field of knowledge of conflict management scientific projects, which includes recommendations for conflict response planning.

Considering the specificity of scientific projects, there is a need to integrate risk management, conflict and behavioral economics using the model of "Change Management Iceberg", proposed by F. Krueger [20]. According to F. Krueger's observations, a large part of project managers pay attention only to the visible part of it, forgetting that the main levers do not lie on the surface. Surface control is the top of the iceberg. At this level of management is the management of costs, quality, time. Deep control is the lower part of the iceberg. At this level, there is a management of changes and implementations: management of perceptions and beliefs; management of power and political power. According to F. Kruger, real changes require profound changes in the behavior of team members, their values, affecting the redistribution of power $[20,21]$.

\section{Research results}

In general, the management process consists in the purposeful influence on the system in order to achieve the desired state. Modern project management methodology includes separate processes for managing each area of knowledge separately, in particular resource management and project stakeholders [1, 2, 4].

To ensure the success of the project, it is necessary to integrate the processes of risk management, conflict, and behavioral economics into one process. This is due to the fact that in any modern science, these issues are considered (Fig. 1). 


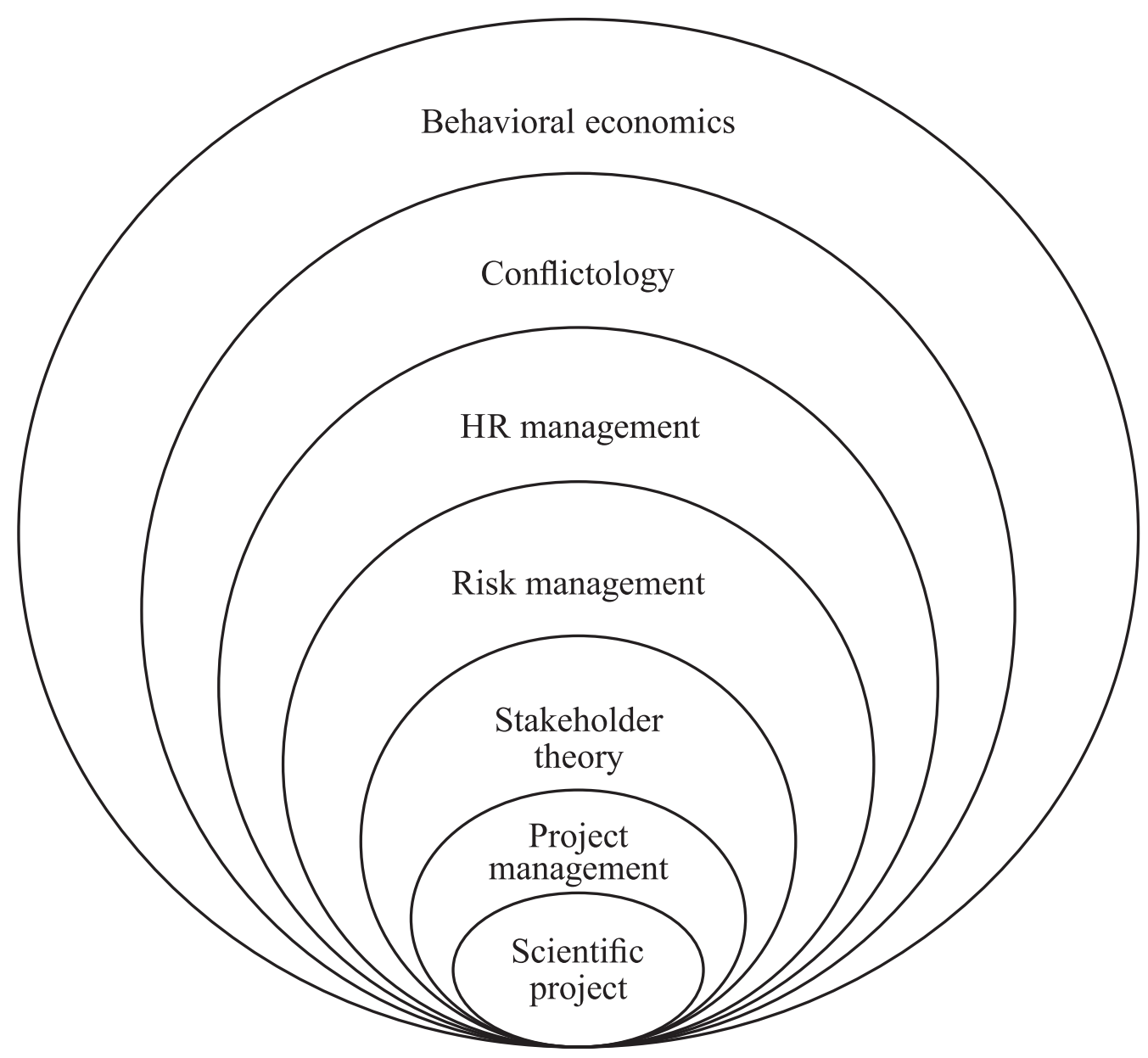

Fig. 1. Integration of methodologies in scientific project management

Integrated risk management of scientific project conflicts in a behavioral economics is a process that involves influencing various uncertainties (risks, conflicts, factors of behavioral economics) simultaneously, and which aims to reduce or eliminate all negative consequences in a scientific project, completing it within the approved budget, deadlines and established quality.

The essence of integrated risk management of scientific project conflicts in behavioral economics is to apply a single process of managing various uncertainties, regardless of the reasons for their occurrence.

The conceptual scheme of integrated anti-risk conflict management of a scientific project in behavioral economics is given in Fig. 2 . 


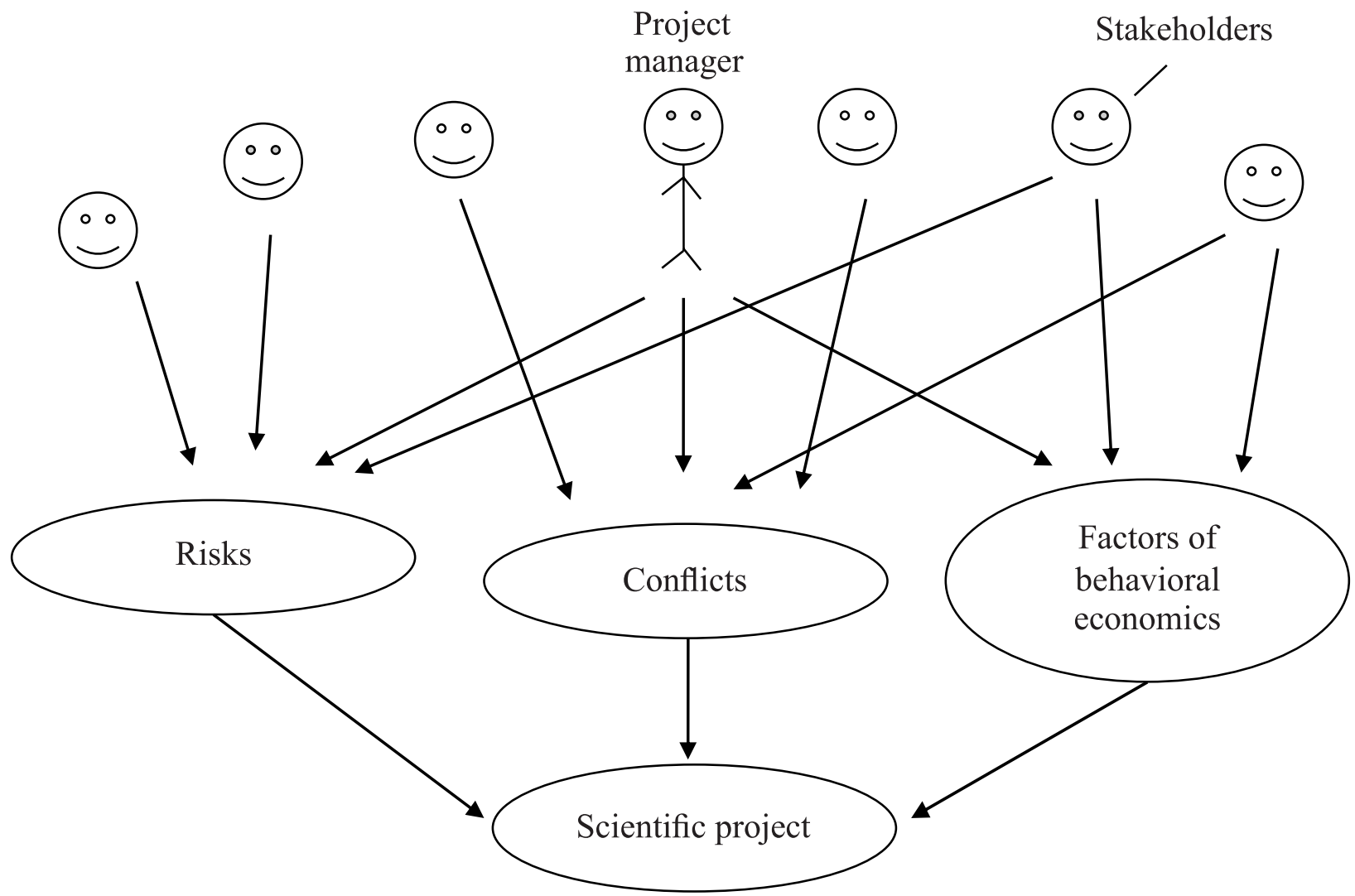

Fig. 2. The conceptual scheme of integrated anti-risk conflict management of a scientific project in a behavioral economics

From Fig. 2. it is seen that the activities of stakeholders of the research project may create uncertainties (risks, conflicts, factors of behavioral economics), which must be managed through integrated risk management of conflicts of the scientific project in a behavioral economics.

The conceptual model of integrated anti-risk conflict management of a scientific project in a behavioral economics is built using the model of "Change Management Iceberg" $[20,21]$ and is shown in Fig. 3.

Since the peculiarity of the iceberg is that a larger amount of the ice is underwater than on the surface of the water. As the projection on a scientific project, it can be represented as follows: environment, stakeholders, partly risks and conflicts, factors of behavioral economics are above the water surface, and most risks and conflicts are underwater. 


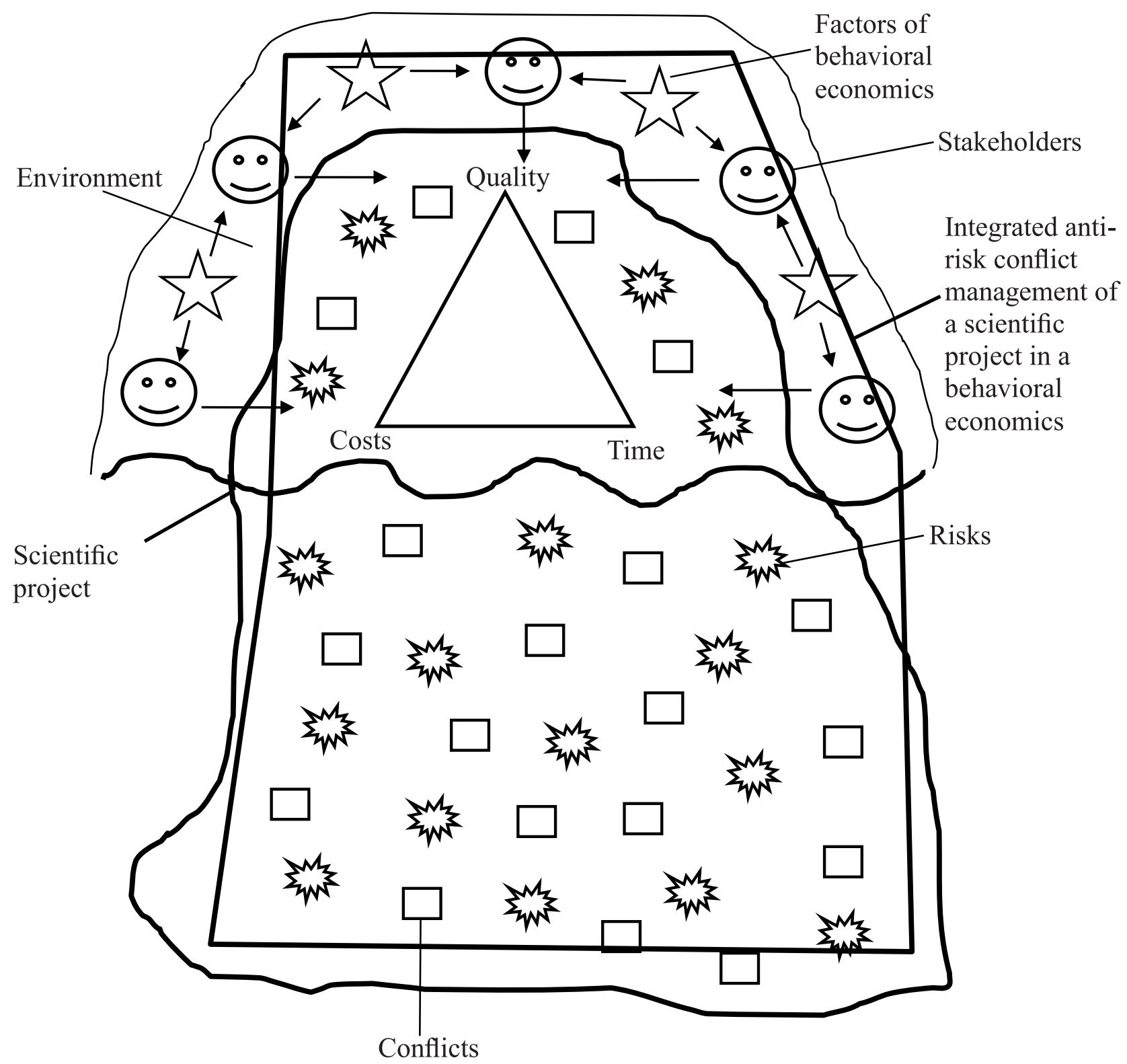

Fig. 3. Model "Iceberg" of integrated anti-risk conflict management of a scientific project in a behavioral economics

Human behavior sometimes seems paradoxical, so the main task of the head of a scientific project and his team is to constantly monitor, recognize and build their behavior accordingly.

A scientific project can be conditionally considered as an iceberg, the surface part of which is what its stakeholders demonstrate to others, it is also called the rational part, or the level of facts $[20,21]$. It includes visible information, facts "on the surface", the topic of conversation, conscious perception, rationality. There is also an underwater part that the stakeholders of the scientific project are trying to hide, in particular: emotions, need, desire, values, principles, relationships, prejudice, instincts.

Unlike existing classical management projects, including cost, time and quality that are on the surface of the iceberg in the conceptual model of integrated management of conflicts scientific project in terms of behavioral economics is proposed to manage risks and conflicts under the water, which is not visible from the outside. 
During the process of implementation of a scientific project, the project manager often pays attention to the fact that the stakeholder does not perceive us when it is too late, in particular, information passes by his attention or even irritates him. That is why timely recognition of the emotional state of the stakeholder is an important factor in building effective communication.

\section{Inference}

1. The study analyzes the methods of integrating the management of risks, conflicts and factors of behavioral economics. It was found that different sciences offer their methods and tools for managing uncertainties such as: risks, conflicts and factors of behavioral economics.

2. The necessity of building integrated anti-risk conflict management in the conditions of behavioral economics is substantiated. A conceptual scheme of a single process of managing various uncertainties was obtained, regardless of the reasons for their occurrence. This will allow comprehensive management of risks, conflicts and factors of behavioral economics of stakeholders for the successful completion of a scientific project.

3. Conceptual modeling of integrated anti-risk conflict management of a scientific project in a behavioral economics using the "Change Management Iceberg" model is carried out. As a result, a conceptual model of integrated anti-risk conflict management of a scientific project in a behavioral economics was developed, which combined separate areas of knowledge of project management, conflict management, risk management, behavioral economics. This result provided an effective tool for integrated management of risks, conflicts and factors of behavioral economics of stakeholders, which will be useful in the process of studying the irrational behavior of stakeholders of any project.

\section{References}

1. A Guide to the Project Management Body of Knowledge (PMBOK® Guide) (2017). Sixth Edition. USA. PMI, 574.

2. Individual competence baseline for Project, Program and Portfolio management (IPMA ICB) (2015). IPMA. Version 4.0. 431.

3. Freeman R.E. (2010). Stakeholder Theory: The State of the Art. Cambridge University Press. 300.

4. Bushuev, S., Bushueva, N., Babaev, I., Yakovenko V., Grisha E., Dzyuba S., \& Vojtenko, A. (2010). Kreativnye tekhnologii upravleniya proektami i programmami. Monografiya. K.: «Sammit-Kniga», 768.

5. Demarko, T., \& Lister, T. (2005). Chelovecheskiy faktor: uspeshnyye proyekty i komandy. SPb, Symbol Plus, 200.

6. Sepeda Huaman, D.F. (2018). Model' otochennya orhanizatsiynoho proektu $v$ umovakh povedinkovoyi ekonomiky. 3th Mizhnarodnoyi naukovo praktychnoyi konferentsiyi «Project, Program, Portfolio Management». Odessa, ONPU, 89-91.

7. Bedrii, D. (2017). Osoblyvosti proektno-oriyentovanoho upravlinnya naukovymy proektamy. 2th International Scientific and Practical Conference «Project, Program, Portfolio Management». Odessa, ONPU, 15-18.

8. Bushuyev S., Bushuyev D. \& Neizvestnyy S.I. (2020, June). Konvergentsiya i gibridizatsiya metodologiy upravleniya proyektami. Scientific Journal of Astana IT University, vol. 2, 86-101. DOI: 10.37943/AITU.2020.22.12.008.

9. Bushuyeva, N., Kozyr', B. \& Zaprivoda A.A. (2020, June). Mnogourovnevoye gibridnoye upravleniye infrastukturnimi programammi. Scientific Journal of Astana IT University, vol. 2, 71-85. DOI: 10.37943/AITU.2020.20.47.007.

10. Neizvestnyy, S., Neizvestnyy N. \& Sheshukov M. (2019). Primeneniye konvergentnykh tekhnologiy upravleniya $v$ programmakh proyektov vysokoy neopredelennosti tselepolaganiya. Osobennosti protsessa tselepolaganiya. Upravleniye proyektami i programmami, vol. 4, no. 60, 290-299.

11. Piterska, V.M. (2018). Ryzyko-oriyentovane upravlinnya naukovoyu diyal'nistyu zakladiv vyshchoyi osvity $v$ ramkakh innovatsiynykh program. Avtoref. Dys. Odessa, ONMU, 42 p. 
12. Danchenko, O.B. (2015). Metodolohiya intehrovanoho upravlinnya vidkhylennyamy v proektakh. Avtoref. Dys. Kyiv, KNUBA, 45.

13. Yakovleva, E.A. (2016). Analiz vozmozhnostey ispol'zovaniya printsipov povedencheskoy ekonomiki dlya prinyatiya effektivnykh upravlencheskikh resheniy. Sovremennyye tekhnologii upravleniya, vol. 5, no. 65, art. 6504. https://sovman.ru/article/6504/.

14. Taleb, N.N. (2015). Chernyy lebed'. Pod znakom nepredskazuyemosti. Moscow: KoLibri, 736.

15. Bedrii, D. (2020). Development of a model of integrated risk and conflict management of scientific project stakeholders under conditions of behavioral economics. Technology audit and production reserves, vol. 3, no. 2(53), 9-14. DOI: 10.15587/2706-5448.2020.207086.

16. Danchenko, O.B, Bedrii, D. \& Semko, I. (2018). Kontseptual'na model' formuvannya vysokoefektyvnoyi komandy naukovoho proektu". Visnyk NTU «KhPl». Kharkov, NTU «KhPI» Publ., no. 1 (1277), 51-56. DOI: 10.20998/2413-3000.2018.1277.8.

17. Zatserkovnyy, V.I., Oberemok, I.I., Oberemok, N.V., \& Yehorchenkova, N.Yu. (2016). Intehratsiya protsesiv upravlinnya proektom na etapi planuvannya $v$ biznes-protsesy kompaniyi. Technology audit and production reserves, no. 6/1(32), 35-42. DOI: 10.15587/2312-8372.2016.86176.

18. Project Management Institute (2014). Navigating Complexity: A Practice Gide. Newtown Square, PA: Author.

19. Danchenko, O., Bedriy, D. \& Semko I. (2019). Upravlinnya konfliktamy naukovoho proektu. VisnykNTU «KhPI». Kharkov, NTU «KhPI» Publ., no. 2 (1327), 28-35. DOI: 10.20998/2413-3000.2019.1327.5.

20. Aysberg upravleniya izmeneniyami [Elektronnyy resurs] / Wilfried Kruger. Rezhim dostupa: http:// www.12manage.com/methods_change_management_iceberg_ru.

21. Ladon'ko, L.S., \& Hanzha, I.V. (2015). Sutnist' ta modeli upravlinnya zminamy na pidpryyemstvi. Naukovyy visnyk Polissya, №2(2), 101-108.

\section{Литература}

1. A Guide to the Project Management Body of Knowledge (PMBOK® Guide). (2017). Sixth Edition. USA. $\mathrm{PMI}, 574 \mathrm{p}$.

2. Individual competence baseline for Project, Program and Portfolio management (IPMA ICB). (2015). IPMA. Version 4.0. $431 \mathrm{p}$.

3. Freeman R.E. (2010). Stakeholder Theory: The State of the Art. Cambridge University Press. 300 p.

4. Бушуев С.Д., Н.С. Бушуева., и И.А. Бабаев. (2010). Креативные технологии в управлении проектами и программами: монография. и др. К.: Саммит книга, 768.

5. Демарко, Т., Листер, Т. (2005). «Человеческий фактор: успешные проекты и команды». - СПб.: Символ-Плюс. 200.

6. Гуамман, Д.Ф. Модель оточення організаційного проекту у сфері обслуговування літаків в умовах поведінкової економіки. Project, Program, Portfolio Management: матеріали Третьої Міжнародної науково-практичної конференції. Одеса : ОНПУ. 89-91.

7. Бедрій, Д.І. (2017). Особливості проектно-орієнтованого управління науковими проектами. Project, Program, Portfolio Management: матеріали Другої Міжнародної науково-практичної конференції 08-09 грудня 2017 року. Т. 2. Одесса: ОНПУ, 15-18.

8. Бушуев, С.Д. (2020). Конвергенция и гибридизация методологий управления проектами / С.Д. Бушуев, Д.А. Бушуев, С.И. Неизвестный. Scientific Journal of Astana IT University, 2, 86-101. DOI: 10.37943/AITU.2020.22.12.008.

9. Бушуева, Н.С., Козырь, Б.Ю., и Запривода, А.А. (2020). Многоуровневое гибридное управление инфраструктурными программами. Scientific Journal of Astana IT University. 2, 71-85. DOI: 10.37943/AITU.2020.20.47.007.

10. Неизвестный, С.И., Шешуков, М.А. (2019). Применение конвергентных технологий управления в программах проектов высокой неопределенности целеполагания. Особенности процесса целеполагания. Управление проектами и программами, 4(60), 290-299.

11. Пітерська, В.М. (2018). Ризико-орієнтоване управління науковою діяльністю закладів вищої освіти в рамках інноваційних програм: автореф. дис. д-ра техн. наук: 05.13.22. Одесса, ОНМУ, 42. 
12. Данченко, О.Б. (2015). Методологія інтегрованого управління відхиленнями в проектах: автореф. дис. д-ра техн. наук: 05.13.22. Київ, КНУБА, 45.

13. Яковлева, Е.А. (2015). Анализ возможностей использования принципов поведенческой экономики для принятия эффективных управленческих решений // Современные технологии управления, 5(65). Номер статьи: 6504. Режим доступа: https://sovman.ru/article/6504/.

14. Талеб, Н.Н. (2015). Черный лебедь. Под знаком непредсказуемости. М.: КоЛибри, 736.

15. Bedrii, D. (2020). Development of a model of integrated risk and conflict management of scientific project stakeholders under conditions of behavioral economics / Dmytro Bedrii // Technology audit and production reserves. 3, 2(53). 9-14. DOI: 10.15587/2706-5448.2020.207086.

16. Данченко, О.Б., Бедрій, Д.І., и Семко, І.Б. (2018). Концептуальна модель формування високоефективної команди проєкту, Вісник НТУ «ХПІ». Серія: Стратегічне управління, управління портфелями, програмами та проєктами. - Х.: НTУ «XПI», 1(1277), 51-56. DOI: 10.20998/24133000.2018.1277.8.

17. Зацерковний, В.І., Оберемок, І.І., Оберемок, Н.В., и Єгорченкова, Н.Ю. (2016). Інтеграція процесів управління проектом на етапі планування в бізнес-процеси компанії. Технологічний аудит та розвиток виробництва. 6/1(32), 35-42. DOI: 10.15587/2312-8372.2016.86176.

18. Project Management Institute. (2014). Navigating Complexity: A Practice Gide. Newtown Square, PA: Author.

19. Данченко О.Б. Бедрій, Д.І., и Семко, І.Б. (2019). Управління конфліктами наукових проектів. Вісник НТУ «ХПІ». Серія: Стратегічне управління, управління портфелями, програмами та проектами. Х.: НТУ «ХПІ», №2(1327), 28-35. DOI: 10.20998/2413-3000.2019.1327.5.

20. Айсберг управления изменениями [Электронный ресурс] / Wilfried Kruger. - Режим доступа: http://www.12manage.com/methods_change_management_iceberg_ru.

21. Ладонько, Л.С., и Ганжа, І.В. (2015). Сутність та моделі управління змінами на підприємстві. Науковий вісник Полісся. - №2(2), 101-108. 